\title{
A LESSON IN VALUATION FROM ESTONIA: THE DIFFERENCE BETWEEN THE FUNDAMENTAL VALUE OF EQUITY UNDER DISTRIBUTED AND TRADITIONAL PROFIT TAXATION SYSTEMS
}

\author{
Mark KANTŠUKOV ${ }^{1}$, Priit SANDER ${ }^{2}$ \\ University of Tartu, Tartu, Estonia \\ E-mails: ${ }^{1}$ ecomark@ut.ee (corresponding author); ${ }^{2}$ priit.sander@ut.ee
}

Received 21 April 2018; accepted 07 June 2018

\begin{abstract}
Corporate value creation and management are one of the key issues for any business enterprise. A gap exists in research into the implications of the distributed profit taxation $(D P T)$ system in Estonia for corporate value creation. Under the Estonian system of corporate taxation, companies need not pay income tax on undistributed earnings, allowing them to postpone income tax liability indeterminately. This theoretical paper compares the relationship between a company's equity value and taxation of profits under traditional (or classical) (TPT) and DPT systems. A TPT system is a system where the amount of corporate income tax is determined by the profit the company earned during the taxation period. We show that fundamental equity value under a DPT system should be higher vis-à-vis equity value under a TPT system (ceteris paribus). To illustrate this, we use a dividend discount model and values from a hypothetical company. The equity value under DPT is also higher when financial leverage is considered. The results suggest that conventional valuation models and their inputs should be adjusted when valuing Estonian companies. Ignoring these adjustments runs the risk of undervaluing the equity of Estonian companies, as well as the equity of companies operating under similar tax regimes.
\end{abstract}

Keywords: equity valuation, dividend discount model, distributed profit taxation, financial leverage, theoretical finance.

JEL Classification: C02, G12, H25.

\section{Introduction}

The value of a company depends on many factors, external and internal. Usually one can think of variety of companyspecific factors, such as company's sales revenue, profitability, cost of financing, quality of management etc. A multi-layered framework of determinants of corporate value is provided by Sander (2007). Hence the valuation - the process of establishing the value of a company - may rely on smaller or larger number of various factors, depending on the valuation approach applied. However, it is possible to claim that each valuation has to deal with the issue of corporate taxes.

Taxes are one of the main sources of confusion in corporate valuation. It is not only important to consider different types of taxes, tax rates on various sources of income, and their effect on shareholders' wealth, but also taxation rules and procedures that vary by country. One of the challenges is to properly adjust valuation models with those tax-related rules and procedures. One of the most important issues is related to corporate income tax, or profit tax, i.e. tax imposed on the income (pre-tax profit, earnings before tax) of companies or similar legal entities.

In this paper, we investigate the effect of the Estonian system of distributed profit taxation on the valuation of equity, which so far has not been studied. Under distributed profit taxation $(D P T)$, the mechanism of corporate income tax liability formation is different from that under classical profit taxation. This may raise the need to adjust the approach to the valuation of Estonian companies. The issue is of practical importance, as among Estonian valuation practitioners there is neither guidance nor consensus regarding the adjustment of valuation models for distributed profit tax (Kantšukov and Sander 2016).

Copyright $\odot 2018$ The Authors. Published by VGTU Press.

This is an Open Access article distributed under the terms of the Creative Commons Attribution License (http://creativecommons.org/licenses/by/4.0/), which permits unrestricted use, distribution, and reproduction in any medium, provided the original author and source are credited.. 
While the amount of corporate income tax under a classical taxation system is determined by the profit the company earned during the taxation period, then under a distributed profit taxation system, which was introduced in Estonia in 2000, companies only have to pay income tax (or profit tax) on the distributed part of their profits. ${ }^{1}$ Profits could be legally distributed in the form of dividends, share buybacks or a share capital reduction, whereas in most of the cases there is no taxation of distributed profit at the recipient level (Income Tax Act 2018). A similar system was introduced in Georgia in 2017 (EY Georgia Tax \& Law Brief 2016), and in Latvia in 2018 (Corporate Income Tax 2018). It is worth mentioning that largely due to the DPT system, Estonia has held top position in the Corporate Tax Rank of the International Tax Competitiveness Index (International Tax Competitiveness Index 2017).

Technically, the DPT system allows a company to defer its income tax liability for an infinite period of time. From the shareholders' perspective, this situation potentially creates an advantage for a company operating in Estonia (Georgia, Latvia) - a company operating under the $D P T$ regime should be more valuable than a company running its business under a traditional profit taxation regime. The impact of distributed profit taxation on the value of DPT-based companies has not been discussed in the literature before; hence, it is possible to state that there is a clear research gap, and the present study intends to fill it.

Theoretical discussion on the relationship between corporate income tax and corporate valuation has been extensive but mainly US-centred. This can be traced back to seminal papers by Modigliani and Miller (1958), Modigliani and Miller (1963), Brennan (1970), and Brennan and Schwartz (1978) where the impact of tax is considered via financial policy (capital structure) and/ or dividend policy. A significant portion of the US tax system based research is dedicated to amendments to a conventional dividend discount model (DDM), also known as the Gordon model, and corporate and/or personal income taxes. Notable theoretical studies in this field include papers by Haugen and Heins (1969), Gordon and Gould (1978), O’Brien (1991), and Pointon (1996). The framework of the present study is quite close to that of Denis and Sarin (2002), where the difference in the values of companies with different corporate taxation statuses (i.e. $\mathrm{S}$ and $\mathrm{C}$ corporations) was considered.

\footnotetext{
Starting from 2018 resident credit institutions and affiliated branches of non-resident credit institutions are an exception to this system - they have to pay quarterly advance payments of income tax based on the previous quarter's taxable profit. As of the end of 2017, this exception applies to less than a couple of dozen organisations - the list of credit institutions can be found on the homepage of the Estonian Financial Supervisory Authority (Finantsinspektsioon - Credit Institutions 2018).
}

Considering adjustments to the valuation formulae under unconventional tax systems, then numerous papers are devoted to valuation adjustments under a dividend imputation system. ${ }^{2}$ Ashton (1989), and Monkhouse (1993, 1996, 1997) developed and adjusted a capital asset pricing model (CAPM), weighted average cost of capital (WACC) and adjusted present value (APV) methodology under an imputation tax system. Officer (1994) demonstrated the importance of imputation credits in the valuation of companies. Lally (2000) developed valuation formulae for situations, where both dividend imputation and differential taxation of interest and capital gains are presented.

Still, so far there are no credible academic papers dedicated to amendments to the traditional valuation models under the DPT system. In our article, we develop debtadjusted and tax-adjusted dividend discount models to study the effect of distributed profit taxation on equity value. The aim of this paper is to demonstrate that theoretically under a distributed profit taxation regime, equity value is higher compared to a traditional (classical) profit taxation regime (ceteris paribus). Using numerical values for a hypothetical company, we compare equity values under different taxation and leverage scenarios.

This paper contributes to the scarce body of theoretical research (Hazak 2007, 2008, 2009, Sander 2005, Sander and Kantšukov 2009, Sander et al. 2014) on the linkage between distributed profit taxation and corporate finance. Our contribution is directly related to the study of the impact of distributed profit taxation on the valuation of companies. Furthermore, because there are no papers that discuss valuation outcomes resulting from differences in the principles of corporate income taxation for financially leveraged and unleveraged companies, the following work seeks to contribute to this domain as well. The fact that several countries use the DPT system and several more countries are considering switching to distributed profit taxation (presumably due to tax competition), makes this research even more topical. Our results should be interesting to practitioners who value and/or invest in Estonian companies.

The remainder of the paper is structured as follows. In Section 1, we introduce the methodological framework and the model assumptions and present the debt-adjusted and tax-adjusted equity valuation models. In Section 2, we compare the models of equity value under different taxation and leverage situations. The last section summarizes with conclusions and implications.

\footnotetext{
2 According to this system some or all of the tax paid by a firm may be passed on (imputed) to the shareholders in the form of tax credit to lower the amount of income tax payable on a profit distribution. This prevents double taxation for shareholders of the company (Imputation 2016). Dividend imputation system is effective in Australia, Canada, Chile, Malta, Mexico and New Zealand; United Kingdom and Korea have modified dividend imputation system (OECD. Stat. 2017).
} 


\section{The model}

\subsection{Foundations and assumptions}

When developing tax- and debt-adjusted valuation models, we proceed from methodological approach applied in earlier analogous studies, e.g. Haugen and Heins (1969), Gordon and Gould (1978), O’Brien (1991), Pointon (1996), Denis and Sarin (2002), Cooper and Nyborg (2008), Molnár and Nyborg (2013). Our point of departure is the dividend discount model, which is one of the simplest models to estimate equity value. In this respect, our study is similar to studies by Haugen and Heins (1969), O'Brien (1991) and Pointon (1996). The DDM formula can be found in every textbook on valuation and in its conventional form is as follows (Damodaran 2006):

$$
P_{0}=\frac{D P S_{1}}{k_{e}-g}=\frac{D P S_{0} \cdot(1+g)}{k_{e}-g},
$$

where $P$ denotes fundamental share value, DPS represents dividends per share, $g$ denotes dividend (equity) growth rate, and $k_{e}$ is cost of equity.

In the formula (1) and subsequent formulas subindexes 0 and 1 denote, respectively, the present period's values and those of the following period. By multiplying the share value by the number of shares of a company one gets the total equity value. Hence, according to the DDM, equity value is a function of dividend payments, cost of equity and dividend growth rate. This model contains several serious flaws resulting from the set of assumptions:

- the company uses only equity financing,

- the company's profits are not taxed,

- no transaction costs exist,

- there is no inflation,

- all the indicators remain constant.

Some flaws may be considered not so serious (e.g. there are companies continually operating without debt), but ignoring a few of the prerequisites in practice may lead to a misvaluation, especially when comparing the values of companies operating under different conditions.

Before deriving the valuation models, some necessary rearrangements should be made. First of all, the dividend growth rate depends on the company's return on equity and (dividend) payout ratio as follows (Damodaran 2006):

$$
g=R O E \cdot(1-\delta),
$$

where $R O E$ is return on equity and $\delta$ denotes payout ratio (share of the current year's net profit paid out as dividends). The component $(1-\delta)$ is the retention ratio. The payout ratio $\delta$ can vary from 0 to 1 , inclusively. In practice, the payout ratio can be temporarily higher than 1 (a company pays out all the current year profit plus some of its retained earnings) or be negative (i.e. a company with net loss pays out dividends from retained earnings), but in our framework a company may distribute a maximum of $100 \%$ of its current year's net earnings (at which $\delta=1$ and $(1-\delta)=0$ ).

Dividend payments depend on payout ratio and earnings (per share). In turn, company earnings depend on the return on equity and equity book value. As it is assumed that the company only uses equity financing then equity equals assets, net income is equal to operating income (the latter in our case is also equivalent to earnings before interest and taxes, or EBIT); therefore, return on equity $R O E$ is equivalent to return on assets $\frac{E B I T}{A}$ :

$$
D P S_{1}=E_{1} \cdot \delta=B_{0} \cdot R O E \cdot \delta=A_{0} \cdot R_{A} \cdot \delta,
$$

where $E$ denotes earnings per share, $B$ denotes equity book value per share, $A$ denotes total assets per share, $R_{A}$ is total return on assets, where $R_{A}=\frac{E B I T}{A}$.

Using conditions (2) and (3) it is possible to rewrite equation (1) so that the relationship takes the form:

$$
P_{0}=\frac{A_{0} \cdot R_{A} \cdot \delta}{k_{e}-R_{A} \cdot(1-\delta)} .
$$

For the sake of the comprehensibility of derivations, the analytical framework can be separated into four situations:

1. No financial leverage, no profit taxation (proceeding from the classical Gordon-Shapiro model).

2. The company's profit is taxed but the company doesn't use debt capital.

3. The company has financial leverage but profit taxation is absent.

4. The company has both financial leverage and taxation of profit.

Profit taxation in valuation models is to be taken into account according to either a traditional (classical) profit taxation scheme (hereafter - TPT) or distributed profit taxation. Practically, incorporation of all previously mentioned aspects means an adjustment of the dividend discount model for six different cases (see Table 1 below). The numbers also denote the order of the derivation of the equity valuation model for a particular case. Letter $L$ denotes financial leverage.

\begin{tabular}{|c|c|c|c|}
\hline & & \multicolumn{2}{|c|}{ Financial leverage } \\
\hline & & No & Yes \\
\hline \multirow{3}{*}{$\begin{array}{l}\text { Profit } \\
\text { taxation }\end{array}$} & No & $(0)-$ & (3) L (Levered) \\
\hline & $\begin{array}{l}\text { TPT (Total Profit } \\
\text { Taxation) }\end{array}$ & (1) $\mathrm{TPT}$ & (4) $L, T P T$ \\
\hline & $\begin{array}{l}\text { DPT (Distributed } \\
\text { Profit Taxation) }\end{array}$ & (2) DPT & (5) $L, D P T$ \\
\hline
\end{tabular}

Table 1. Possible combinations of financial leverage, total profit and distributed profit taxation regimes in equity valuation (source: compiled by authors) 
At this point several hypotheses about the relationship of equity values in different scenarios can be set up. The main statements could be as follows:

1. Equity value in a situation without profit taxation is higher in comparison with equity value under either TPT or DPT schemes (ceteris paribus). This is a self-evident proposition but it can be considered a condition necessary to verify our calculations.

2. Equity value under $D P T$ is higher than equity value under TPT regardless of the level of financial leverage (ceteris paribus).

3. The difference between equity value under TPT and equity value under $D P T$ is not constant, it depends on the dividend payout ratio (ceteris paribus).

As the formula for equity value in a base-case (or, zerocase) scenario was already presented earlier, and then we start derivations of formulas for scenario (1). In addition to what has been indicated in this paper above, the following indications in the derivation process are also used: $D$ stands for debt per share, $k_{a}$ denotes weighted average cost of capital, $r$ denotes interest rate on debt (the cost of debt), $d$ stands for debt-to-assets ratio $(D / A)$ as a characteristic of financial leverage, and $t$ is profit (dividend) tax rate.

In turn, our elaboration of the models is based on the following assumptions:

1. Equity value is derived from an investor's perspective taking into account future discounted dividends; capital gains are not taken into consideration. Resulting from that only dividend tax and no capital gain tax is present. This assumption can be interpreted as a lack of an aftermarket for an asset - the asset is valuable while it generates a stream of dividends.

2. Double taxation is absent - profit is taxed only once and at the corporate level. In the case of TPT, all after-interest profit is taxed, in the case of DPT only the portion of the after-interest profit distributed to shareholders is taxed. This assumption is not unrealistic: there are countries with traditional profit taxation schemes - e.g. Brazil, Cyprus, Hong Kong where dividends are not taxed (International Core of Excellence 2017, Taxation and investment in Cyprus 2017)

3. We proceed from the proposition of Modigliani and Miller (1958) according to which, under a no taxation condition, corporate value is determined using the firm's ability to generate cash flows in the future and the riskiness of the underlying assets; capital structure is irrelevant. In other words, under this proposition, changing the proportion of debt in the company's capital structure influences the allocation of cash flows to shareholders and creditors but the total value of the company remains unchanged.
When taxes are in play, the total value of a firm is the same as in the situation with the absence of taxation but part of the value goes to the state in the form of discounted future profit tax payments.

4. The analysis is based on the framework by Miles and Ezzell (1980) - the company maintains a constant level of financial leverage (debt-to-assets ratio), and with an increase of equity, the amount of debt capital is also increased so that the $D / A$ remains the same. The constancy of the cost of capital, return on assets, cost of debt, tax rate and dividend payout ratio is also assumed.

5. For the results to be mathematically sound the company's dividend (equity) growth rate should be lower than the cost of capital $-g<k_{e}$.

As evident, the valuation framework is relatively simple, with only a few inputs, which makes it possible to better clarify the implications of the profit taxation regime for equity valuation. Although the dividend discount model suffers from many assumptions, and might not be the most useful model from a practical perspective, it still serves the purpose of the study.

\subsection{Tax and debt-adjusted equity valuation models}

\subsubsection{Traditional profit taxation (TPT), no financial} leverage (1)

As previously mentioned in the case of traditional profit taxation, all the profit (earnings after interest payments) is taxed at tax rate $t$. Proceeding from the residual dividend policy, the amount to be distributed as dividends is smaller compared to when there is an absence of taxation. Earnings per share in this situation are determined as:

$$
E_{1, T P T}=A_{0} \cdot R_{A} \cdot(1-t) \text {. }
$$

And dividend per share is:

$$
D P S_{1, T P T}=E_{1, T P T}-A_{0} \cdot R_{A} \cdot(1-\delta)=A_{0} \cdot R_{A} \cdot(\delta-t) .
$$

Using the results of formulas (5) and (6), we can find the dividend payout ratio of a company under traditional (classical) profit tax as follows:

$$
\delta_{T P T}=\frac{D P S_{1, T P T}}{E_{1, T P T}}=\frac{A_{0} \cdot R_{A} \cdot(\delta-t)}{A_{0} \cdot R_{A} \cdot(1-t)}=\frac{\delta-t}{1-t} .
$$

The equity value for the company can be expressed as:

$$
\begin{aligned}
& P_{0, T P T}=\frac{A_{0} \cdot R_{A} \cdot(1-t) \cdot\left(\frac{\delta-t}{1-t}\right)}{k_{a}-R_{a} \cdot(1-t) \cdot\left(1-\frac{\delta-t}{1-t}\right)}= \\
& \frac{A_{0} \cdot R_{A} \cdot(\delta-t)}{k_{a}-R_{A} \cdot(1-\delta)} .
\end{aligned}
$$




\subsubsection{Distributed profit taxation (DPT), no financial leverage (2)}

Unlike the traditional profit taxation case, only the distributed part of the earnings is taxed under $D P T$, while reinvested earnings are not taxed. As a result, a company that follows a residual dividend policy under DPT shall have the potential to pay out more dividends compared to the same conditions under TPT; this also implies higher a dividend payout ratio vis-à-vis $\delta_{T P T}$ :

$$
\delta_{D P T}=\frac{\delta \cdot(1-t)}{1-\delta \cdot t} .
$$

Finding EPS and DPS under DPT is a little more complex compared to $T P T$, as the profit tax amount depends on the distributed net dividend, not on before-tax earnings. It is possible to express the net earnings of the company under $D P T$ in the following way:

$$
\begin{aligned}
& E_{1, D P T}=E B T_{1, D P T}-T_{1, D P T}= \\
& A_{0} \cdot R_{A}-\frac{t}{1-t} \cdot D P S_{1, D P T} .
\end{aligned}
$$

The amount of reinvested earnings can be defined as:

$$
E_{1, D P T}-D P S_{1, D P T}=A_{0} \cdot R_{A} \cdot(1-\delta) .
$$

Rewriting equation (11) results in the following relationship:

$$
D P S_{1, D P T}=E_{1, D P T}-A_{0} \cdot R_{A} \cdot(1-\delta) .
$$

By substituting the dividend expression from equation (12) into formula (10) it is possible to derive earnings as a function of assets, return on assets, tax rate and $\delta$ :

$$
E_{1, D P T}=A_{0} \cdot R_{A} \cdot(1-\delta \cdot t) .
$$

Hence, dividend per share is equal to:

$$
D P S_{1, D P T}=A_{0} \cdot R_{A} \cdot \delta \cdot(1-t) .
$$

One can check that the dividend payout ratio in formula (9) is indeed equal to the ratio in the right-hand part of formula (14) and the right-hand part of formula (13).

Again, the dividend growth rate is a function of return on assets $R_{A}$ and retention rate $(1-\delta)$ as in all the previous cases. Finally, we can express equity value as:

$$
P_{0, D P T}=\frac{A_{0} \cdot R_{A} \cdot \delta \cdot(1-t)}{k_{a}-R_{A} \cdot(1-\delta)} .
$$

\subsubsection{Financial leverage, no profit taxation (3)}

Most of the companies use debt, so it will be appropriate to clarify the difference in equity value for leveraged firms. First of all, let's amend the framework by introducing corporate leverage without taxation.

Derivation in this part is largely in concordance with the derivation procedure in Leibowitz (2002). In the case where $R_{A}$ is different from $k_{a}$, enterprise value depends on the amount of investments made. In the case where $R_{A}>k_{a}$, larger investments result in higher enterprise value. From the value maximization perspective, it is reasonable to assume that an unleveraged company proceeds from the residual dividend policy, which means that it reinvests its profits into all its investment projects with expected positive net present value $(N P V)$. Proceeding from the relationship in equation (2), according to which the dividend growth rate $g$ is equal to $R O E \cdot(1-\delta)$, assumption 5 can be reorganized as follows:

$$
\delta>1-\frac{k_{e}}{R O E} .
$$

Equation (16) implies that the higher the ROE the higher the minimum payout ratio should be. If the company, under the same conditions, used debt capital then it would not be rational to invest more than in the case without debt - the amount of projects with positive NPV stays the same. To ensure that the amount of earnings to be invested is similar to a no-leveraged case, the following relationship must hold in order to determine the dividend payout ratio $\delta_{L}$ of a leveraged company:

$$
\delta_{L}=1-\frac{R_{A} \cdot(1-\delta) \cdot(1-d)}{R_{A}-r \cdot d} .
$$

One can verify that when $d=0$, then the payout ratio of a leveraged company $\delta_{L}$ is simply equal to $\delta$.

The derivation goes as follows. First of all, the dividend payout ratio of a leveraged company shows a share of afterinterest earnings to be distributed. Leveraged earnings per share are smaller vis-à-vis unleveraged earnings by the amount of the interest payment:

$$
\begin{aligned}
& E_{1, L}=E B I T_{1, L}-I_{1, L}= \\
& A_{0} \cdot R_{A}-A_{0} \cdot r \cdot d=A_{0} \cdot\left(R_{A}-r \cdot d\right) .
\end{aligned}
$$

Dividend per share equals earnings less reinvested profit:

$$
\begin{aligned}
D P S_{1, L} & =E_{1, L}-E_{1} \cdot(1-d) \cdot(1-\delta)= \\
& A_{0} \cdot\left(R_{A}-r \cdot d\right)-A_{0} \cdot R_{A} \cdot(1-d) \cdot(1-\delta)= \\
& A_{0} \cdot\left[R_{A}-r \cdot d-R_{A} \cdot(1-d) \cdot(1-\delta)\right] .
\end{aligned}
$$

For clarification: in formula (19) $E$ without subscript $L$ denotes earnings of an unleveraged company, which must be adjusted by $(1-d) \cdot(1-\delta)$ to get the amount of reinvested profit of a leveraged company. Dividing the result of formula (19) by that of formula (18) leads to the dividend payout ratio of a leveraged company - formula (17). Equation (17) assures that financial leverage does not affect enterprise value.

Next, considering that a company's weighted average cost of capital is the weighted sum of the cost of equity and the cost of debt, the cost of equity can be rearranged so that:

$$
k_{e}=k_{a}+\left(k_{a}-r\right) \cdot \frac{D_{0}}{P_{0, L}} .
$$


Placing formula (20) into the Gordon-Shapiro model (4) we get:

$$
\begin{aligned}
& P_{0, L}=\frac{D P S_{1, L}}{k_{a}+\left(k_{a}-r\right) \cdot \frac{D_{0}}{P_{0, L}}-g_{L}}= \\
& \frac{D P S_{1, L}-\left(k_{a}-r\right) \cdot d \cdot A_{0}}{k_{a}-g_{L}} .
\end{aligned}
$$

Analogically to equation (2), the dividend growth rate of a leveraged company is a function of the return on equity and retention ratio of a leveraged company:

$$
g_{L}=R O E_{L} \cdot\left(1-\delta_{L}\right) .
$$

Leveraged $R O E$ can be found by dividing leveraged earnings in formula (18) by the book value of equity of the leveraged company; replacing $\delta_{L}$ with the expression in formula (17) that leads to:

$$
\begin{aligned}
& g_{L}=\frac{R_{A}-r \cdot d}{1-d} \cdot \frac{R_{A} \cdot(1-\delta) \cdot(1-d)}{R_{A}-r \cdot d}= \\
& R_{A} \cdot(1-\delta) .
\end{aligned}
$$

As the company follows a residual dividend policy, the incorporation of debt capital does not change the growth of dividends. By the way, one can check that the dividend growth rate is the same in all the cases described hereafter; for this reason we will not provide a derivation of the dividend growth rate for the remaining scenarios. Substituting $D P S_{1}$ and $\delta_{L}$ into the Gordon-Shapiro model we get:

$$
P_{0, L}=\frac{A_{0} \cdot\left[R_{A} \cdot \delta \cdot(1-d)+\left(R_{A}-k_{a}\right) \cdot d\right]}{k_{a}-R_{A} \cdot(1-\delta)} .
$$

By dividing the value of the leveraged company's share by its earnings, the price-to-earnings for a leveraged company can be expressed as in Leibowitz (2002).

\subsubsection{Financial leverage with traditional profit taxation (4)}

Practically, this situation implies the combination of scenarios (1) and (3), where financial leverage and profit taxation were reckoned separately. If a leveraged company under traditional profit taxation follows a residual dividend policy, then its dividend payout ratio is calculated as:

$$
\begin{aligned}
& \delta_{L, T P T}=\frac{D P S_{1, L, T P T}}{E_{1, L, T P T}}= \\
& \frac{\left(R_{A}-r \cdot d\right) \cdot(1-t)-R_{A} \cdot(1-\delta) \cdot(1-d)}{\left(R_{A}-r \cdot d\right) \cdot(1-t)} .
\end{aligned}
$$

The result in formula (25) can be achieved through an analytical discussion similar to the derivation of the results in formulas (7) and (17). The equity value of a leveraged company under traditional profit taxation regime is defined as:

$$
\begin{aligned}
& P_{0, L, T P T}= \\
& \frac{A_{0} \cdot\left[\left(R_{A}-k_{a}\right) \cdot d+R_{A} \cdot \delta \cdot(1-d)-t \cdot\left(R_{A}-r \cdot d\right)\right]}{k_{a}-R_{A} \cdot(1-\delta)} .
\end{aligned}
$$

If the financial leverage ratio $d$ and tax rate $t$ are equal to 0 , then equity value in formula (26) reduces to its conventional form presented in equation (4).

It shall be additionally mentioned that the cost of capital $k_{a}$ in scenario (4) does not contain an interest tax shield (i.e. debt interest rate $r$ was not brought to the after-tax level). Consequently, equity value formula (26) already contains an interest tax shield that can be interpreted as the discounted value of the stream of future tax liability savings. However, if we bring the debt interest rate to the after-tax level then formula (26) needs to be readjusted and complemented with the value of the interest tax shield.

\subsubsection{Financial leverage with distributed profit taxation (5)}

This situation is a combination of scenarios (2) and (3). For simplicity in the derivation of the payout ratio, it is more convenient to derive DPS first of all and then EPS because under distributed profit taxation, the earnings per share depend on the amount of income tax paid, which in turn depends on dividends per share. Hence, knowing that the dividends per share of a leveraged company under distributed profit taxation equals:

$$
D P S_{1, L, D P T}=E_{1, L, D P T}-E_{1} \cdot(1-\delta) \cdot(1-d),
$$

then the expanded equation is as follows:

$$
\begin{aligned}
& D P S_{1, L, D P T}=A_{0} \cdot R_{A}-A_{0} \cdot r \cdot d- \\
& \frac{t}{1-t} \cdot D P S_{1, L, D P T}-A_{0} \cdot r \cdot d \cdot(1-\delta) \cdot(1-d) .
\end{aligned}
$$

As a remark, as dividend per share is based on net dividends, then the amount of income tax payable should be calculated by multiplying it by the component $\frac{t}{1-t}$. From equation (28) we can extract the dividends per share:

$$
\begin{aligned}
& D P S_{1, L, D P T}=A_{0} \cdot \\
& {\left[R_{A}-r \cdot d-R_{A} \cdot(1-\delta) \cdot(1-d)\right] \cdot(1-t) .}
\end{aligned}
$$

Re-inserting the right-side of equation (29) into formula (27) we get earnings per share for the company as follows:

$$
\begin{aligned}
& E_{1, L, D P T}= \\
& A_{0} \cdot\left[\left(R_{A}-r \cdot d\right) \cdot(1-t)-t \cdot R_{A} \cdot(1-\delta) \cdot(1-d)\right] .
\end{aligned}
$$

Incorporating financial leverage and distributed profit taxation results gives us a modified dividend payout ratio under a residual dividend policy: 


$$
\begin{aligned}
& \delta_{L, D P T}=\frac{D P S_{1, L, D P T}}{E_{1, L, D P T}}= \\
& \frac{A_{0} \cdot\left[R_{A}-r \cdot d-R_{A} \cdot(1-\delta) \cdot(1-d)\right] \cdot(1-t)}{A_{0} \cdot R_{A}-r \cdot d \cdot A_{0}-\frac{t}{1-t} \cdot D P S_{1, L, D P T}}= \\
& \frac{(1-t) \cdot\left[R_{A}-r \cdot d-R_{A} \cdot(1-\delta) \cdot(1-d)\right]}{\left(R_{A}-r \cdot d\right) \cdot(1-t)+t \cdot R_{A} \cdot(1-\delta) \cdot(1-d)}
\end{aligned}
$$

Finally, the equity value of a leveraged company under distributed profit taxation can be expressed as

$$
\begin{aligned}
& P_{0, L, D P T}= \\
& \frac{D P S_{1, L, D P T}-\left(k_{a}-r\right) \cdot D_{0}}{k_{a}-g}= \\
& \frac{A_{0} \cdot\left[(1-t) \cdot\left(R_{A}-r \cdot d-R_{A} \cdot(1-\delta) \cdot(1-d)\right)-\left(k_{a}-r\right) \cdot d\right]}{k_{a}-R_{A} \cdot(1-\delta)} .
\end{aligned}
$$

Again, if $d$ and $t$ equal 0 , then the result in formula (32) can be reduced to formula (4). Further, one can verify that setting only $t$ to 0 will result in the transformation of equation (32) to equation (24), and by setting only $d$ to 0 will reduce formula (32) to formula (15).

Dividing formula (32) by formula (26) provides the ratio of the equity value for a leveraged $D P T$-based company over the equity value of a leveraged TPT-based company, which shows how much $P_{0, L, D P T}$ should be higher than $P_{0, L, T P T}$ (holding that the payout ratio, profit tax rate, financial leverage, cost of debt and capital, and return on assets are the same for both companies). This ratio looks complex and is irreducible, it does not provide an instant clue that the equity of one company should be more valuable than the equity of another. One can, however, check that this ratio cannot be lower than 1 .

The formulas are quite complicated to instantly grasp the difference between the fundamental equity values under different taxation regimes. For this reason we conduct a comparative analysis of fundamental equity values under a TPT and DPT-based system using the example of a hypothetical company.

\section{Comparative analysis of leveraged and tax-adjusted fundamental equity values}

To illustrate the results obtained in the previous part of this paper we analyse them on the basis of a hypothetical company. Conjointly this analysis should contribute to a confirmation of the statements regarding the relationship between the values set up in Section 2. We model separately the dependence of the fundamental share price on the dividend payout ratio, the return on assets and the cost of capital. This allows us to observe the possible convergence/ divergence of equity values under different scenarios.

We use arbitrary albeit convenient numerical values (except the profit tax rate) so that the dividend payout ratio $\delta$ satisfies condition (5). The values for the cost of capital, return on assets and dividend payout ratio are base values. The numbers are as follows:

- total assets per share $\left(A_{0}\right)-1000$ (euros),

- cost of capital $\left(k_{a}\right)-15 \%$,

- return on assets $\left(R_{A}\right)-20 \%$,

- dividend payout ratio $(\delta)-50 \%$,

- financial leverage $(d)-30 \%$,

- debt interest rate $(r)-5 \%$,

- profit tax rate $(t)-20 \%$.

A profit tax rate of $20 \%$ corresponds to the current Estonian income tax rate. The debt interest rate is set higher than the current level of market interest rates to better visualize unleveraged versus leveraged company scenarios. For clarity of the results we analyse only those situations where return on assets $R_{A}$ exceeds the cost of capital $k_{a}$, but jumping ahead it is possible to state that the relationship between the values is the same in situations where return on assets is smaller than the cost of capital.

In cases where assets return more than investors require, increase in $R_{A}$ and the dividend growth rate $g$ shall lead to the growth of equity value, whereas an increase in WACC leads to a decrease in equity value. However, it is interesting to observe the impact of taxation regimes combined with leveraging. Next, Figure 1 helps to illustrate the dependence of equity value on payout ratio under different scenarios. Keeping in mind assumption (5) presented above, the payout ratio of the company should be higher than $25 \%$. However, the lower limit of the dividend payout ratio in Figure 1 is set at $37.5 \%$ for better visibility of the difference in equity values under different scenarios at higher payout ratios.

Here it is clear that in a no-tax situation, the share price of an unleveraged company is higher than that of a leveraged company. This is a trivial conclusion as in the latter situation assets are partially funded by debt and partially by equity, and total company value is the same in both cases. The difference between $P_{0, L}$ and $P_{0}$ equals the value of debt per share, and this remains constant regardless of the dividend payout ratio.

Considering scenarios with taxation, then the share price of a company operating under TPT is lower than that under $D P T$, this difference becomes smaller under higher dividend payout ratios (i.e. smaller dividend growth rate). In extreme cases, where $\delta=100 \%$ the values for $P_{0, T P T}$ and $P_{0, D P T}$ are equal. This outcome is in accordance with the assumptions of the analysis. Further, it is possible to note 
here that the equity value of a leveraged company operating under DPT is still higher than that of a leveraged company operating under a classical profit taxation scheme. The convergence of share prices takes place in this situation as well: when all earnings are distributed (i.e. the dividend growth rate equals $0 \%$ ) then the equity values of companies operating under the different taxation regimes are equal.

The functional relationship between equity values and return on assets follows the same pattern (see Figure 2 below). In Figure 2, return on assets is set to change within a range of $15 \%$ (at which it is equal to the cost of capital) to $25 \%$.
The relationship between equity value and return on assets is positive. When earnings are not taxed and $R_{A}=k_{a}$ then fundamental equity value is equal to its book value; in the case of taxation, the fundamental equity value is smaller than its book value, as part of the value goes to state in the form of income tax. When comparing equity values under $T P T$ and $D P T$, then in a zero-leverage situation the percentage difference between $P_{0, T P T}$ and $P_{0, D P T}$ remains constant regardless of return on assets (ceteris paribus), $P_{0, D P T}$ is higher than $P_{0, T P T}$ by $\frac{t \cdot(1-\delta)}{\delta-t}$ percent or $\approx 33.33 \%$ in our case. So, for unleveraged TPT and DPT-based

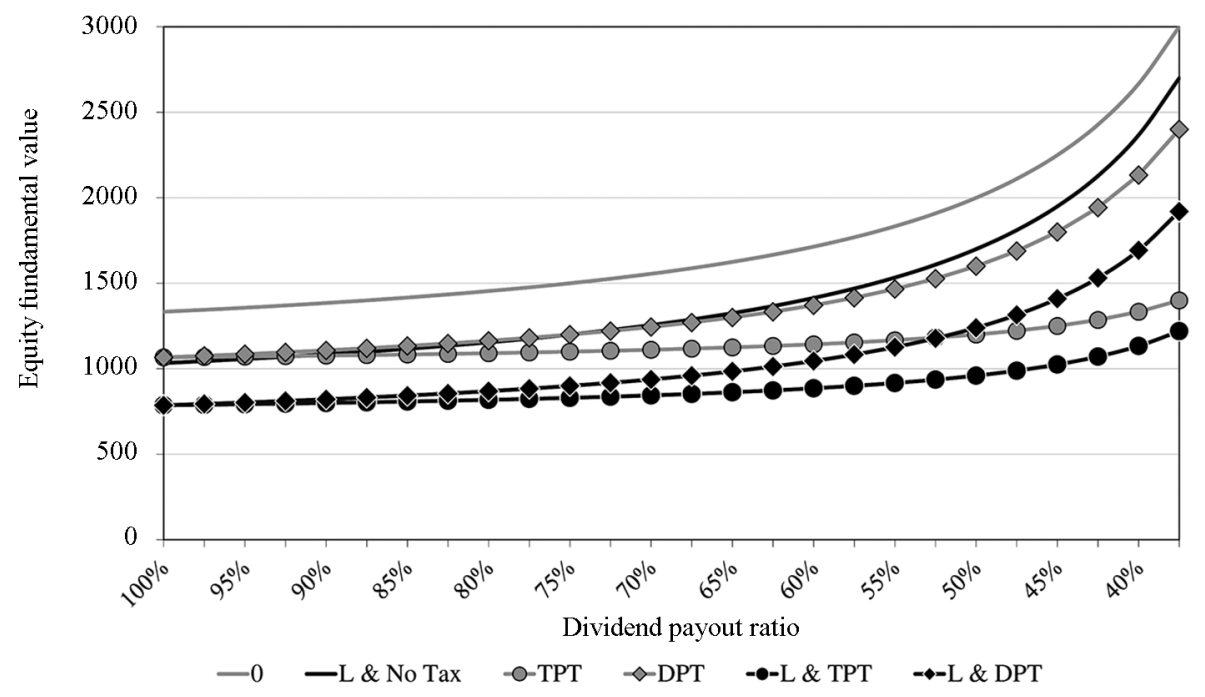

Figure 1. Equity value as a function of the payout ratio under different scenarios (equity value on the vertical axis, payout ratio on the horizontal axis) (source: authors' calculations)

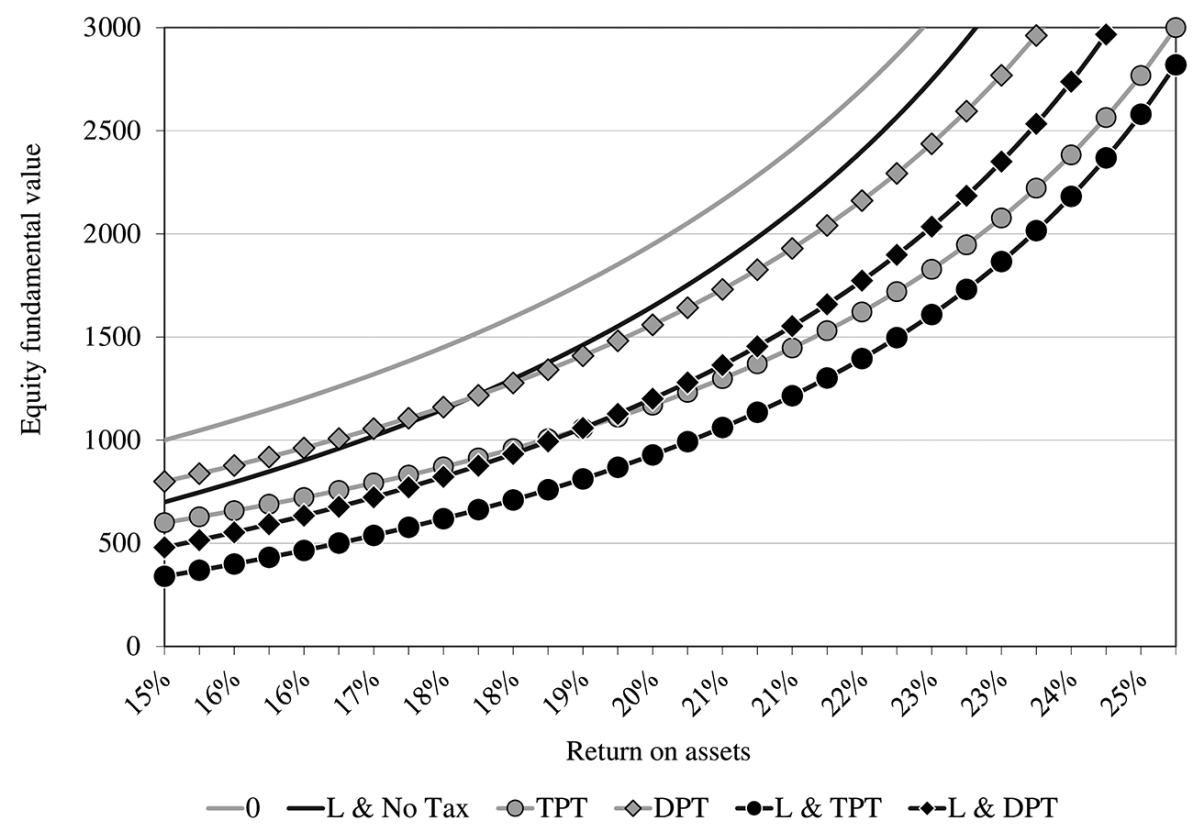

Figure 2. Equity value as a function of return on assets under different scenarios (equity value on the vertical axis, return on assets on the horizontal axis) (source: authors' calculations) 
companies, the difference between their values depends only on the payout ratio and income tax rate. However, for leveraged companies, the percentage difference between share values of TPT-based and DPT-based companies is smaller at higher rates of $R_{A}$, although this difference reaches an asymptotic value of $\frac{t \cdot(1-\delta) \cdot(1-d)}{\delta+d \cdot(1-\delta)-t}$ percent; in our case it equals $\approx 15.56 \%$. The impact of return on assets on the share value of leveraged companies reveals itself in combination with the payout ratio, financial leverage and income tax rate - for TPT-based companies an increase in $R_{A}$ results in a quicker rise in the value compared with that of DPT-based companies (ceteris paribus).

Finally, the next Figure below (Figure 3) depicts the relationship between equity value and the cost of capital.

Apparently, increasing the cost of capital affects equity values negatively under all scenarios. As with the dependence of the equity value of an unleveraged company on return on assets, the percentage difference between $P_{0, T P T}$ and $P_{0, D P T}$ is constant (the share value of the DPT-based company is higher than the share value of the TPT-based company by the same $\frac{t \cdot(1-\delta)}{\delta-t}$ percent) but divergence between $P_{0, L, T P T}$ and $P_{0, L, D P T}$ increases with the rise in the cost of capital. This situation can be considered analogous to the dependence of share value on return on assets: for leveraged companies the impact of the cost of capital is combined with leverage and income tax; under the rising cost of capital $P_{0, L, T P T}$ decreases faster than $P_{0, L, D P T}$.

The results of the modelling using the example of a hypothetical company show that indeed, the Estonian system of corporate income taxation has a dissimilar effect on fundamental equity value compared with that of traditional profit taxation. The propositions in subsection 1.1 above turned out to be true. Valuing companies operating under a $D P T$ regime on the same basis as companies operating under a TPT regime leads to the undervaluation of the former enterprises (ceteris paribus). For example, based on the values of inputs listed at the beginning of this section, the theoretical share value of a leveraged company under TPT should be 960 euros, and the theoretical share value of a leveraged company under DPT should equal 1,240 euros. This means that if the $D P T$-based company is treated akin to the TPT-based company then the former is undervalued by approximately $22.6 \%$ (in a non-leveraged situation those share values should be 1,200 and 1,600 euros respectively; the undervaluation of the $D P T$-based company in this case is $25.0 \%$, which equals the tax rate on net dividends, i.e. $\left.\frac{t}{1-t}\right)$.

As one can see from Figures 1-3, this extent of undervaluation is not a constant value, as the magnitude of the undervaluation of a company operating under a DPT system depends on how precisely an analyst estimates the company's future input variables - return on assets, cost of capital, payout ratio among others - and the company's expected or target capital structure. The point is that, although the model used in the present analysis is very simple, the results and conclusions should hold for other valuation approaches as well.

\section{Conclusions}

Corporate valuation is an important issue for any sizeable company. Besides many fundamental factors valuation practitioners have to deal with the impact of corporate income tax (profit tax). Different principles of corporate income taxation dissimilarly affect the value of equity. In our stylized model, we demonstrated that the share price

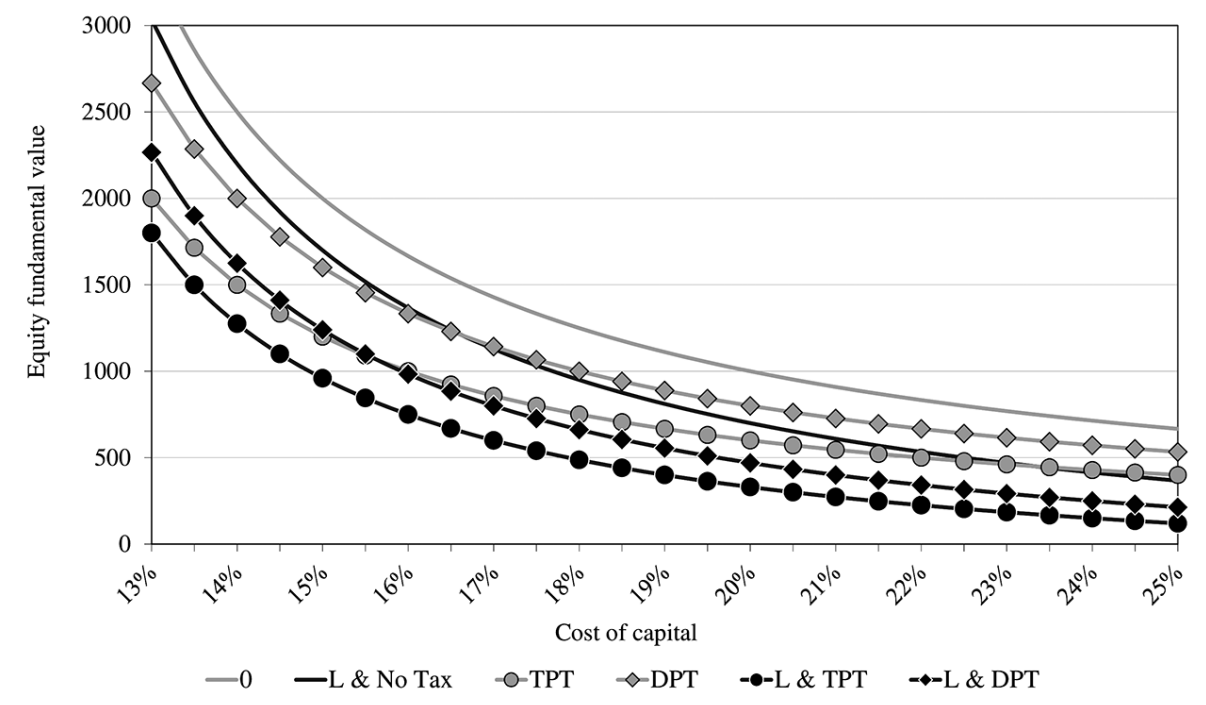

Figure 3. Equity value as a function of the cost of capital under different scenarios (equity value on the vertical axis, cost of capital on the horizontal axis) (source: authors' calculations) 
(equity value) of a company operating under a distributed profit taxation regime should be higher than the share price of a company operating under traditional profit taxation (ceteris paribus). This finding applies to both unleveraged and leveraged companies. The divergence between the equity value of a TPT-based and DPT-based company increases with the rise in return on assets (which means that the shift to the $D P T$ system had a greater positive impact on profitable companies) and decreases with a growing dividend payout ratio and cost of capital. The difference in values in favour of the DPT-based company is still positive when the company's return on assets is smaller than its cost of capital.

This analysis raises the question of whether the effect of distributed profit taxation is observable in the case of the shares of Estonian public companies. One serious obstacle, which makes it almost impossible to empirically control for the presence of this effect, is that the number of publicly traded Estonian companies is small. One cannot form a representative sample of public Estonian companies to clarify the impact of the distributed profit taxation system.

There are also some limitations to the research related to the aspect of the endogeneity of the value. It is known that due to information asymmetry and transaction costs, external financing for companies can be insufficient. Since under the DPT system, companies retain more earnings compared with the TPT system, then there is greater availability of internal financing for firms operating under the distributed profit taxation system. This implies that if there is an investment project with positive $N P V$, then it may not be green lighted by a company operating under the TPT system due to the scarcity of internal financing and inaccessibility of external financing. Under the DPT system, a company has more internal resources to launch investment projects with positive NPV. This additionally contributes to the valuation advantage of $D P T$-based companies vis-à-vis TPT-based companies.

Furthermore, when assessing the value of ownership in a company, it is more appropriate to estimate the value at a personal level; that is, to assess the after-tax wealth a shareholder can pocket. From this point of view not only corporate but also personal income taxes have to be taken into account: there may be a low corporate income tax rate but relatively high personal income tax rate and vice versa. However, in Estonia, dividends paid by a resident company to a natural person resident are not taxed at a personal level. This implies that from the point of view of an Estonian natural person resident, the valuation formulas for $D P T$-based companies derived in this paper do not have to be adjusted.

Nevertheless, an essential implication of the distributed profit taxation system for valuation is that Estonian companies, as well as other firms working in the environment with distributed profit taxation, should not be valued the same way as companies subject to traditional (classical) profit tax.
Neglecting the necessary tax-related adjustments may lead to serious (under)valuation errors for Estonian companies. This is an important implication that valuation practitioners must keep in mind.

It may seem that this topic is of local importance but this may become a vital issue for foreign investors operating in Estonia and other countries with a similar system of corporate income taxation. The results of this study are also important in the context of cross-border mergers and acquisitions (M\&A), where either buyer or seller is outside of the country with DPT.

The present study did not address all the aspects related to the impact of distributed profit taxation on equity value. There are other issues that can be elaborated in future research. One of these is related to the adjustment of other discounted cash flow-based valuation models (e.g. free cash flow to equity) as well as discount rates - primarily cost of equity - under the DPT system. Of particular interest would be to compare the optimal holding period of an investment asset under different taxation regimes. In future work, the present framework can be expanded to integrate corporate and personal income tax into the valuation setting. The latter aspect is especially topical due to the proposed differential taxation of dividends in Estonia. Starting from 2018, Estonian companies paying dividends on the regular basis have to pay $14 \%$ of income tax instead of $20 \%$. However, the dividends paid to private individuals are subject to an additional $7 \%$ income tax, where those dividends have been paid by an Estonian company and are subject to the corporate income tax rate of 14\% (Income Tax Act 2018). This change raises potential valuation issues for international corporate groups with ownerships in Estonian companies which extends this topic beyond the domestic context.

\section{Acknowledgments}

The authors would like to express their gratitude to senior research fellow Dr. Jaan Masso (University of Tartu), Dr. Anna Broughel (University of Maryland, College Park), associate professor Janis Berzins (BI Norwegian Business School), Dr. Nicolas Gavoille (Stockholm School of Economics in Riga) for their valuable comments and remarks on the paper, senior research fellow Dr. Oliver Lukason (University of Tartu) for his advice and moral support, and Mr. Michael Haagensen for proofreading the paper.

\section{References}

Ashton DJ (1989) The cost of capital and the imputation tax system. Journal of Business Finance \& Accounting 16 (1): 75-88. https://doi.org/10.1111/j.1468-5957.1989.tb00005.x

Brennan MJ (1970) Taxes, market valuation and corporate financial policy. National Tax Journal 23: 417-427. http://www.jstor. org/stable/41792223 
Brennan MJ, Schwartz ES (1978) Corporate income taxes, valuation, and the problem of optimal capital structure. The Journal of Business 51 (1): 103-114. http://www.jstor.org/ stable/2352621

Cooper IA, Nyborg KG (2008) Tax-adjusted discount rates with investor taxes and risky debt. Financial Management 37 (2): 365-379. https://doi.org/10.1111/j.1755-053X.2008.00016.x

Corporate Income Tax (2018) The state revenue service of Latvia https://www.vid.gov.lv/en/node/57208

Damodaran A (2006) Damodaran on valuation: security analysis for investment and corporate finance (2nd ed). Hoboken: Wiley.

Denis DJ, Sarin A (2002) Taxes and the relative valuation of S corporations and C corporations. Journal of Applied Finance, Fall/Winter: 7-16 https://pdfs.semanticscholar.org/9f1c/a8b050b65fa3c8b419043baa271a769cd5bc.pdf

EY Georgia Tax \& Law Brief (2016) 2016 in brief http://www. ey.com/Publication/vwLUAssets/EY-tax-and-law-brief-yearly2016-eng/\$FILE/EY-tax-and-law-brief-yearly-2016-eng.pdf

Finantsinspektsioon - Credit institutions (2018) https://www. fi.ee/index.php?id=3162

Gordon MJ, Gould LI (1978) The cost of equity capital with personal income taxes and flotation costs. The Journal of Finance 33 (4): 1201-1212.

Haugen RA, Heins AJ (1969) The effects of the personal income tax on the stability of equity value. National Tax Journal 22: 466-471. http://www.jstor.org/stable/41791680

Hazak A (2007) Dividend decision under distributed profit taxation: investor's perspective. International Research Journal of Finance and Economics 9: 201-219 https://www.researchgate.net/publication/24137721_Dividend_Decision_under_Distributed_Profit_Taxation_Investor\%27s_Perspective

Hazak A (2008) Profit vs. distributed profit based taxation and companies' capital structure. International Journal of Entrepreneurship and Innovation Management 8: 524-541. https:// doi.org/10.1504/IJEIM.2008.022319

Hazak A (2009) Companies' financial decisions under the distributed profit taxation regime of Estonia. Emerging Markets Finance and Trade 45 (4): 4-12. https://doi.org/10.2753/ REE1540-496X450401

Imputation (2016) Australian taxation office https://www.ato.gov. au/Business/Imputation/

Income Tax Act (2018) Riigi Teataja https://www.riigiteataja.ee/ en/eli/ee/531012018001/consolide/current

International Core of Excellence. Unlocking the World (2017) ICE country highlights, Deloitte https://www2.deloitte.com/ content/dam/Deloitte/us/Documents/Tax/us-tax-ice-countryhighlights-unlocking-the-world.pdf

International Tax Competitiveness Index (2017) https://taxfoundation.org/2017-international-tax-competitiveness-index

Kantšukov M, Sander P (2016) Value in the eye of the beholder: a survey of valuation practices of Estonian financial professionals. Investment Management and Financial Innovations 13 (2-1): 157-172. https://doi.org/10.21511/imfi.13(2-1).2016.04

Lally M (2000) Valuation of companies and projects under differential personal taxation. Pacific-Basin Finance Journal 8 (1): 115-133. https://doi.org/10.1016/S0927-538X(99)00025-6
Leibowitz ML (2002) The levered P/E Ratio. Financial Analysts Journal 55 (6): 68-77. http://www.jstor.org/stable/4480436

Miles JA, Ezzell JR (1980) The weighted average cost of capital, perfect capital markets, and project life: a clarification. The Journal of Financial and Quantitative Analysis 15: 719-730 http://www.jstor.org/stable/2330405

Modigliani F, Miller MH (1958) The cost of capital, corporation finance and the theory of investment. The American Economic Review 48: 261-297 http://www.jstor.org/stable/1809766

Modigliani F, Miller MH (1963) Corporation income taxes and the cost of capital: a correction. The American Economic Review 53: 433-443. http://www.jstor.org/stable/1809167

Molnár P, Nyborg KG (2013) Tax-adjusted discount rates: a general formula under constant leverage ratios. European Financial Management 19 (3): 419-428. https://doi. org/10.1111/j.1468-036X.2011.00619.x

Monkhouse PHL (1993) The cost of equity under Australian dividend imputation tax system. Accounting and Finance 33: 1-18. https://doi.org/10.1111/j.1467-629X.1993.tb00321.x

Monkhouse PHL (1996) The valuation of projects under the dividend imputation tax system. Accounting and Finance 36: 185-212. https://doi.org/10.1111/j.1467-629X.1996.tb00306.x

Monkhouse PHL (1997) Adapting the APV valuation methodology and the beta gearing formula to the dividend imputation tax system. Accounting and Finance 37: 69-88. https://doi. org/10.1111/j.1467-629X.1997.tb00314.x

O'Brien TJ (1991) The constant growth model and personal taxes. Journal of Business \& Accounting 18 (1): 125-132. https://doi. org/10.1111/j.1468-5957.1991.tb00584.x

OECD. Stat (2017) Table II. 4. Overall statutory tax rates on dividend income http://stats.oecd.org/Index.aspx?QueryId=59615

Officer RR (1994) The cost of capital of a company under an imputation tax system. Accounting and Finance 34 (1): 1-17. https://doi.org/10.1111/j.1467-629X.1994.tb00259.x

Pointon J (1996) Inflation, taxation and the valuation of shares. Accounting and Business Research 27 (1): 51-57. https://doi. org/10.1080/00014788.1996.9729531

Sander P (2005) Laenukapitali maksueelis Eestis - müüt või reaalsus? [Tax advantage of debt capital in Estonia - myth or reality?]. In Perspectives for Estonian Entrepreneurship in the European Union. Reports-papers of the III Scientific and Educational Conference, 169-177.

Sander P (2007) Essays on factors influencing financing decisions of companies: risk, corporate control and taxation aspects (Doctoral dissertation).

Sander P, Kantšukov M (2009) Effect of corporate taxation system on profitability and market ratios - the case of ROE and $\mathrm{P} / \mathrm{B}$ ratio. Research in Economics and Business: Central and Eastern Europe 1 (28, 2): 27-40 http://rebcee.eu/index.php/ $\mathrm{REB} /$ article/view/18

Sander P, Teder A, Viikmaa K, Kantšukov M (2014) The distributed profit based corporate taxation, and the valuation of cash holding. International Journal of Trade, Economics and Finance 5 (3): 212-217. https://doi.org/10.7763/IJTEF.2014.V5.373

Taxation and Investment in Cyprus (2017) Deloitte https://www2. deloitte.com/content/dam/Deloitte/global/Documents/Tax/ dttl-tax-cyprusguide-2017.pdf 